\title{
Effect of methoxy stilbenes—analogs of resveratrol—on the viability and induction of cell cycle arrest and apoptosis in human myeloid leukemia cells
}

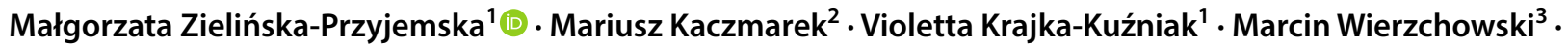 \\ Wanda Baer-Dubowska'
}

Received: 6 May 2020 / Accepted: 11 July 2020 / Published online: 31 July 2020

(C) The Author(s) 2020

\begin{abstract}
The present study aimed to evaluate the cytotoxicity and its mechanism of five synthetic methoxy stilbenes, namely 3,4,4'-trimethoxy, 3,4,2'-trimethoxy, 3,4,2',4'-tetramethoxy, 3,4,2',6'-tetramethoxy, and 3,4,2',4',6'-pentamethoxy-transstilbenes (MS), in comparison with resveratrol (RSV). Human promyelocytic (HL-60) and monocytic leukemia (THP-1) cells were treated with the tested compounds for $24 \mathrm{~h}$, and cytotoxicity, cell cycle distribution, and apoptosis were evaluated. Significant differences were found in the susceptibility of these cell lines to all stilbenes, including RSV. The THP-1 cells were more resistant to cytotoxic activity of these compounds than HL-60 cells. Among the tested stilbenes, 3,4,4'-tri-MS and 3,4,2',4'-tetra-MS exhibited higher cytotoxicity toward both cell lines than RSV and the other methoxy stilbenes. This activity might be related to cell cycle arrest at the G2/M phase and induction of apoptosis. In this regard, 3,4,4'-tri-MS and $3,4,2^{\prime}, 4^{\prime}$-tetra-MS at highest concentrations increased the p53 protein level particularly in HL-60 cells. Moreover, treatment with these derivatives increased the ratio of the proapoptotic Bax protein to the antiapoptotic Bcl-xl protein, suggesting the induction of apoptosis through the intrinsic mitochondrial pathway in both cell lines. Further studies are required to fully elucidate the mechanism of these activities.
\end{abstract}

Keywords Methoxy stilbenes · Resveratrol $\cdot$ Apoptosis $\cdot$ Promyelocytic leukemia cells $\cdot$ Monocytic leukemia cells

$\begin{array}{ll}\text { Abbreviations } \\ \text { DMSO } & \text { Dimethyl sulfoxide } \\ \text { FBS } & \text { Fetal bovine serum } \\ \text { MTT } & \begin{array}{l}\text { 3-(4,5-Dimethylthiazol-2-yl)-2,5-diphe- } \\ \text { nyltetrazolium bromide }\end{array} \\ & \text { Propidium iodide } \\ \text { PI } & \text { Phosphatidylserine }\end{array}$

RNase A Ribonuclease A

\section{Introduction}

Resveratrol (trans-3,5,4'-trihydroxystilbene, RSV), a polyphenolic phytoalexin, possesses well-documented cancer chemopreventive and chemotherapeutic activity [1]. RSV has been shown to inhibit in vitro growth of several cancer cells, including human acute lymphocytic and non-lymphocytic leukemia cell lines such as HL-60 (promyelocytic leukemia) [2], K562 (chronic myelogenous leukemia) [3], and CEM-C7H2 (T-acute lymphocytic leukemia) [4]. Several mechanisms have been proposed for the growth inhibitory effect of RSV, including induction of leukemia cell differentiation, apoptosis, and cell cycle arrest at the $S$ phase and inhibition of DNA synthesis by inhibiting ribonucleotide reductase or DNA polymerase [5].

Regarding apoptosis, RSV was shown to induce both extrinsic and intrinsic apoptosis in HL-60 cells. The intrinsic apoptosis pathway is referred to the mitochondrial apoptosis pathway, while extrinsic apoptosis refers to apoptosis initiated by Fas ligands followed by caspase- 8 cleavage to an activated form, which subsequently cleaves and activates 
caspase-3 or induces BID (a BH3 domain-containing proapoptotic Bcl 2 family member) cleavage, causing BID to translocate to the mitochondria and induce apoptosis through the intrinsic pathway [6].

RSV, however, has several pharmacokinetic limitations. Particularly, the susceptibility of its hydroxyl groups to glucuronidation and sulfation leads to a short half-life and limited bioavailability. Moreover, the cytotoxic effects of RSV on human cancer cells are observed at relatively high concentrations. For example, its growth inhibitory effects were reported at 40-200 $\mu \mathrm{M}$ [7]. The substitution of the hydroxyl group with methoxy groups enhanced the bioavailability of these derivatives in comparison with that of RSV because of increased lipophilicity and resistance to glucuronidation and sulfation [8].

Compared to RSV, its derivatives with ortho-methoxy substituents such as 3,4,5,4'-tetramethoxy-trans-stilbene (DMU212) have been found to be more potent anticarcinogenic agents in some in vitro and in vivo studies $[9,10]$.

Moreover, 3,5,4'-trimethoxystilbene (3,5,4'-tri-MS) has emerged as the most potent proapoptotic analog of RSV [11]. In addition, 3,5,4'-tri-MS and pinostilbene (3,4'-dihydroxy5-methoxystilbene) were reported to be up to 100-fold more cytotoxic than RSV in cancer cell lines [12].

Our previous studies also showed that 3,5,4'-tri-MS caused a massive accumulation of cells at the G2/M phase of the cell cycle and increased the apoptosis rate related to p53 induction in rat $\mathrm{C} 6$ glioma cells [13]. In addition, synthetic 3,4,2'-tri-MS, 3,4,2',4'-tetra-MS, and 3,4,2',4',6'-pentaMS modulated the constitutive expression of enzymes and receptors involved in estrogen metabolism in breast normal and cancer cells more efficiently than RSV [14, 15]. Cytochromes P450 1A1 and 1B1 are crucial for the metabolism of estrogen to their reactive electrophilic forms. The most potent inhibitor of CYP1A1 and $1 \mathrm{~B} 1$ gene expression was 3,4,2',4',6'-penta-MS, which reduced the levels of mRNA transcript and protein of both CYPs from 31 to $89 \%$ of the initial levels in immortalized cells [14].

These data indicate that the number and position of hydroxyl group substituent in stilbene scaffold might be critical for their biological and anticancer activity.

The present study aimed to evaluate the cytotoxicity and ability of tri-, tetra-, and penta-methoxy stilbenes to induce cell cycle arrest and apoptosis in human myeloid leukemia cells.

\section{Materials and methods}

\section{Chemicals}

Methoxy stilbenes, namely 3,4,4'-tri-MS, 3,4,2'-tri-MS, 3,4,2',4'-tetra-MS, 3,4,2',6'-tetra-MS, 3,4,2',4',6'-penta-MS, were synthesized in the Department of Chemical Technology of Drugs, PUMS, as described previously [16]. Diethyl (3,4-dimethoxybenzyl) phosphonate was transformed by the Horner-Wadsworth-Emmons reaction with proper aromatic aldehydes (2-methoxybenzaldehyde or 2,4-dimethoxybenzaldehyde or 2,4,6-trimethoxybenzaldehyde) into the investigated polymethoxy-trans-stilbenes. The structures of all compounds were confirmed by NMR, mass spectra, and elementary analysis. Figure 1 outlines the synthesis of these compounds.

RSV, camptothecin, antibiotic solution (10,000 units penicillin, $10 \mathrm{mg}$ streptomycin, and $25 \mu \mathrm{g}$ amphotericin B per $\mathrm{mL}$ ), dimethyl sulfoxide (DMSO), fetal bovine serum (FBS), glutamine, propidium iodide (PI), ribonuclease A (RNase A), 3-(4,5-dimethylthiazol-2-yl)-2,5-diphenyltetrazolium bromide (MTT), and RPMI 1640 medium were provided by Sigma-Aldrich Co. (St. Louis, MO, USA). Suppliers of antibodies and reagent kits used in this study are indicated in the description of the respective methods.

All other compounds were readily available commercial products. RSV and its methoxy derivatives were dissolved in DMSO at the concentration of $10 \mathrm{mM}$ and stored at $-20^{\circ} \mathrm{C}$.

\section{Cell cultures and treatments}

HL-60 (human acute promyelocytic leukemia) and THP-1 (human acute monocytic leukemia) cell lines were obtained from the ECACC and supplied by Sigma-Aldrich. HL-60 and THP- 1 cells were cultured in RPMI 1640 media supplemented with $10 \%$ FBS, antibiotics, and $2 \mathrm{mM}$ L-glutamine in a fully humidified atmosphere at $37^{\circ} \mathrm{C}$ with $5 \% \mathrm{CO}_{2}$. The cells $\left(1 \times 10^{6} /\right.$ well) were seeded in 6-well plates by resuspension in complete growth media. The cells were then treated with increasing concentrations of methoxy stilbenes and RSV $(1-150 \mu \mathrm{M})$. The incubation was continued for subsequent $24 \mathrm{~h}$ to assess cell cycle distribution, apoptosis, and the levels of $\mathrm{p} 53$, Bax, and Bcl-xl proteins.

Control cells were treated with vehicle (DMSO). Cells treated with $50 \mathrm{nM}$ of camptothecin were used as a positive control. The concentration of DMSO in culture medium did not exceed $0.1 \%$.

\section{Cell viability (MTT) assay}

HL-60 and THP- 1 cells were seeded at $5 \times 10^{4}$ cells/well in a 24-well plate. The cells were incubated in triplicates with different concentrations of methoxy stilbenes or RSV $(1-200 \mu \mathrm{M})$ in a final volume of $100 \mu \mathrm{L}$ of growth medium for 24 and $48 \mathrm{~h}$ at $37^{\circ} \mathrm{C}$ with $5 \% \mathrm{CO}_{2}$. An aliquot of $10 \mu \mathrm{L}$ of MTT solution $(5 \mathrm{mg} / \mathrm{mL})$ was added to each well and incubated for another $4 \mathrm{~h}$. The water-insoluble formazan crystals were solubilized in DMSO before the measurement of absorbance using a microplate reader (TECAN Infinite 


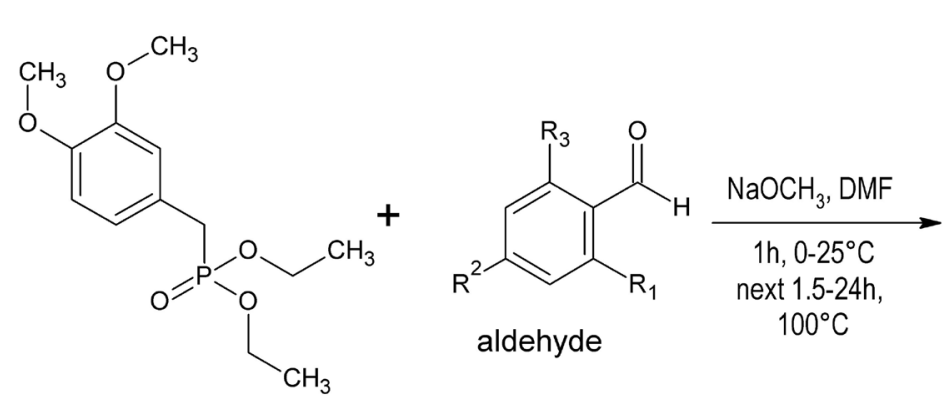

diethyl (3,4-dimethoxybenzyl)phosphonate

$$
\mathrm{R}_{1}, \mathrm{R}_{2}, \mathrm{R}_{3}=\mathrm{H} \text { or } \mathrm{OCH}_{3}
$$<smiles>[R]c1cc([R])c(/C=C/c2ccc(OC)c(OC)c2)c([R])c1</smiles><smiles>COc1ccc(/C=C/c2ccc(OC)c(OC)c2)cc1</smiles>

3,4,4'-tri-MS<smiles>COc1ccccc1/C=C/c1ccc(OC)c(OC)c1</smiles>

3,4,2'-tri-MS<smiles>COc1ccc(/C=C/c2ccc(OC)c(OC)c2)c(OC)c1</smiles>

3,4,2',4'-tetra-MS<smiles>COc1ccc(/C=C/c2c(OC)cccc2OC)cc1OC</smiles>

3,4,2',6'-tetra-MS<smiles>COc1cc(OC)c(/C=C/c2ccc(OC)c(OC)c2)c(OC)c1</smiles>

$3,4,2$ ',4',6'-penta-MS<smiles>Oc1ccc(/C=C/c2cc(O)cc(O)c2)cc1</smiles>

resveratrol

Fig. 1 A scheme of methoxy stilbenes (MS) synthesis and their structures

M200) at $570 \mathrm{~nm}$ (with the reference wavelength at $690 \mathrm{~nm}$ ). All the experiments were repeated three times, with at least three measurements per assay.

\section{Flow cytometric cell cycle analysis}

Cell cycle distribution was evaluated by flow cytometric analysis using PI staining. After treatment, HL-60 and THP-1 cells were collected, washed with PBS, and fixed in $70 \%$ ethanol at $4{ }^{\circ} \mathrm{C}$ for $30 \mathrm{~min}$. The cells were then washed twice in PBS and resuspended in $250 \mu \mathrm{L}$ of PBS containing $50 \mu \mathrm{g} / \mathrm{mL}$ PI and $100 \mu \mathrm{g} / \mathrm{mL}$ RNase A. After incubation in dark at $37{ }^{\circ} \mathrm{C}$ for $30 \mathrm{~min}$, the fluorescence of cells was measured with a FACSCanto flow cytometer (Becton Dickinson, San Jose, CA, USA). Data analysis and acquisition were performed using FACS Diva software (Becton Dickinson).

\section{FITC Annexin V/PI double staining assay}

Apoptosis was determined by Annexin V and PI double staining of treated and non-treated HL-60 and THP-1 cells by using the FITC Annexin V Apoptosis Detection kit (Becton Dickinson) following the manufacturer's procedures. Briefly, harvested cells were washed with PBS, resuspended 
in $100 \mu \mathrm{L}$ of binding buffer, and stained with $5 \mu \mathrm{L}$ of FITC Annexin V labeling reagent and $5 \mu \mathrm{L}$ of PI for $15 \mathrm{~min}$ in dark. Finally, the samples were assessed with a FACSCanto flow cytometer using Cell Quest software. In our study, apoptotic cells included cells with early (Annexin V+, PI-) and late (Annexin $\mathrm{V}+, \mathrm{PI}+$ ) apoptosis, while viable cells were negative for both Annexin V and PI.

\section{Western blot analysis of p53, Bax, and Bcl-xl protein levels}

The immunoblot assay was used to determine the level of p53, Bax, and Bcl-xl proteins. Briefly, after $24 \mathrm{~h}$ culture with various concentrations of methoxy stilbenes or RSV, cell lysates were obtained by extracting HL-60 and THP- 1 cells with RIPA buffer. The concentration of total proteins was determined using the Bradford protein assay (Bio-Rad Laboratories, Hercules, CA, USA). Fifty micrograms of total protein from each concentration was resolved by electrophoresis using $12 \%$ or $10 \%$ SDS-PAGE, followed by electrotransfer onto a polyvinyl difluoride transfer membrane (Immobilon$\mathrm{P}$, Millipore). After blocking with $10 \%$ skimmed milk, the proteins were probed with anti-human p53, Bax, and Bcl$\mathrm{xl}$ antibodies. The $\beta$-actin protein was used as an internal control. As the secondary antibodies in the staining reaction, alkaline phosphatase-labeled anti-goat IgG, anti-mouse $\mathrm{IgG}$, or anti-rabbit IgG was used. Bands were visualized with the Bio-Rad AP Conjugate Substrate Kit NBT/BCIP. The amount of the immunoreactive product in each lane was determined using the Quantity One software (Bio-Rad Laboratories). Values were calculated as relative absorbance units (RQ) per mg protein.

\section{Statistical analysis}

All results are presented as mean \pm SEM from at least three independent experiments. Statistical evaluation was performed with one-way ANOVA and Dunnett's post hoc test using GraphPad Prism Software Version 4.03 (San Diego, CA, USA). Differences were considered to be significant for $p$ values $\leq 0.05$.

\section{Results}

\section{Effect of RSV and methoxy stilbenes on cell viability}

The effect of the tested methoxy stilbenes and RSV on the viability of HL-60 and THP-1 cells was assessed using the MTT assay. Table 1 presents the $\mathrm{IC}_{50}$ values obtained after 24 and $48 \mathrm{~h}$ of incubation with the tested compounds. Significant differences were noted in the effect of these compounds on the viability of HL-60 and THP- 1 cells. The $\mathrm{IC}_{50}$ values in HL-60 cells were approximately two times lower than those obtained in THP-1 cells. Moreover, the cytotoxicity of RSV in comparison with its methoxy analogs in HL-60 cells, particularly after $48 \mathrm{~h}$ treatment, did not differ significantly. In contrast, THP-1 cells were more susceptible to the cytotoxic effect of RSV analogs than to the parent compound. The highest cytotoxicity was shown by 3,4,4'-tri-MS followed by 3,4,2',4'-tetra-MS.

\section{The effect of RSV and methoxy stilbenes on cell cycle distribution}

To assess the effect of RSV and methoxy stilbenes on cell cycle distribution, the HL-60 and THP-1 cells were treated with these compounds for $24 \mathrm{~h}$, and the cell cycle

Table 1 Effect of resveratrol and its derivatives on human HL-60 and THP-1 cell viability (IC50; $\mu \mathrm{M}$ )

\begin{tabular}{|c|c|c|c|c|}
\hline \multirow[t]{3}{*}{ Tested compounds } & \multicolumn{4}{|l|}{ IC50 $(\mu \mathrm{M})$} \\
\hline & \multicolumn{2}{|l|}{ HL-60 } & \multicolumn{2}{|l|}{ THP-1 } \\
\hline & $24 \mathrm{~h}$ & $48 \mathrm{~h}$ & $24 \mathrm{~h}$ & $48 \mathrm{~h}$ \\
\hline 3,5,4'-trihydroxy-trans-stilbene (Resveratrol) & $59.98 \pm 1.54$ & $46.84 \pm 1.92$ & $130.05 \pm 1.37^{\#}$ & $79.02 \pm 1.63^{\# \#}$ \\
\hline 3,4,4'-trimethoxy-trans-stilbene $\left(3,4,4^{\prime}\right.$-tri-MS) & $51.36 \pm 2.09 *$ & $41.32 \pm 1.70$ & $97.25 \pm 3.11 *$ & $62.81 \pm 1.83 *$,\# \\
\hline 3,4,2'-trimethoxy-trans-stilbene(3,4,2'-tri-MS) & $58.27 \pm 1.47$ & $46.34 \pm 1.89$ & $121.41 \pm 2.08^{\#}$ & $75.20 \pm 2.64^{\# \#}$ \\
\hline $3,4,2^{\prime}, 4^{\prime}$-tetramethoxy-trans-stilbene $\left(3,4,2^{\prime}, 4^{\prime}\right.$-tetra-MS $)$ & $55.35 \pm 2.23$ & $43.01 \pm 2.68$ & $117.35 \pm 3.68^{*}$, & $70.48 \pm 2.45^{\# \#}$ \\
\hline $3,4,2^{\prime}, 6^{\prime}$-tetramethoxy-trans-stilbene $\left(3,4,2^{\prime}, 6^{\prime}\right.$-tetra-MS $)$ & $61.32 \pm 3.80$ & $40.00 \pm 3.04$ & $127.60 \pm 3.24^{\#}$ & $77.26 \pm 3.17^{\# \#}$ \\
\hline $3,4,2^{\prime}, 4^{\prime}, 6^{\prime}$-pentamethoxy-trans-stilbene $\left(3,4,2^{\prime} 4^{\prime}, 6^{\prime}\right.$-penta-MS $)$ & $56.85 \pm 1.17$ & $44.52 \pm 2.40$ & $118.52 \pm 3.05^{\#}$ & $77.71 \pm 1.91^{\# \#}$ \\
\hline
\end{tabular}

The cells were treated for 24 and $48 \mathrm{~h}$ with different concentrations of methoxy stilbenes or resveratrol and IC50 values were obtained by plotting $\log (\%$ inhibition $/ 100-\%$ inhibition $)$ vs $\log$ (concentration), where $\%$ inhibition $=(100-$ viability $)$ based on means \pm SEM from three independent experiments

${ }^{*} p<0.05$ compared to resveratrol treated cells; ${ }^{\#} p<0.05$ compared to HL-60 cells treated for $24 \mathrm{~h}$; ${ }^{\# \#} p<0.05$ compared to HL-60 cells treated for $48 \mathrm{~h}$ 
progression was assessed by PI staining of nuclear DNA using flow cytometry. Camptothecin, the DNA topoisomerase I inhibitor, at a final concentration of $50 \mathrm{nM}$ was used as a positive control. Figure 2 presents the results of this assay.

A significant increase in the number of THP-1 cells in the $\mathrm{S}$ phase as a result of camptothecin treatment was observed; this finding is consistent with its described ability to arrest cell cycle in this phase. However, camptothecin treatment of HL-60 myeloid cells led to an increased number of dead cells and reduced the percentage of HL-60 cells in the $S$ phase.

Consistent with the cytotoxicity data, 3,4,4'-tri-MS and $3,4,2^{\prime}, 4^{\prime}$-tetra-MS increased mostly the percentage of cells in the G2/M phase in HL-60 and THP-1 cells. A similar effect was observed after treatment with other methoxy stilbenes, but the percentage of cells in this phase was lower than that observed after treatment with 3,4,4'-tri-MS and 3,4,2',4'-tetra-MS. In contrast, RSV increased the number of cells in the S phase in THP-1 cells. In HL-60 cells, RSV tended to increase the percentage of cells in the $\mathrm{S}$ phase after treatment with lower concentrations $(1-10 \mu \mathrm{M})$, while at higher concentrations $(75-150 \mu \mathrm{M})$, a considerable accumulation of cells in the G0/G1 phase was observed.

$\mathrm{HL}-60$
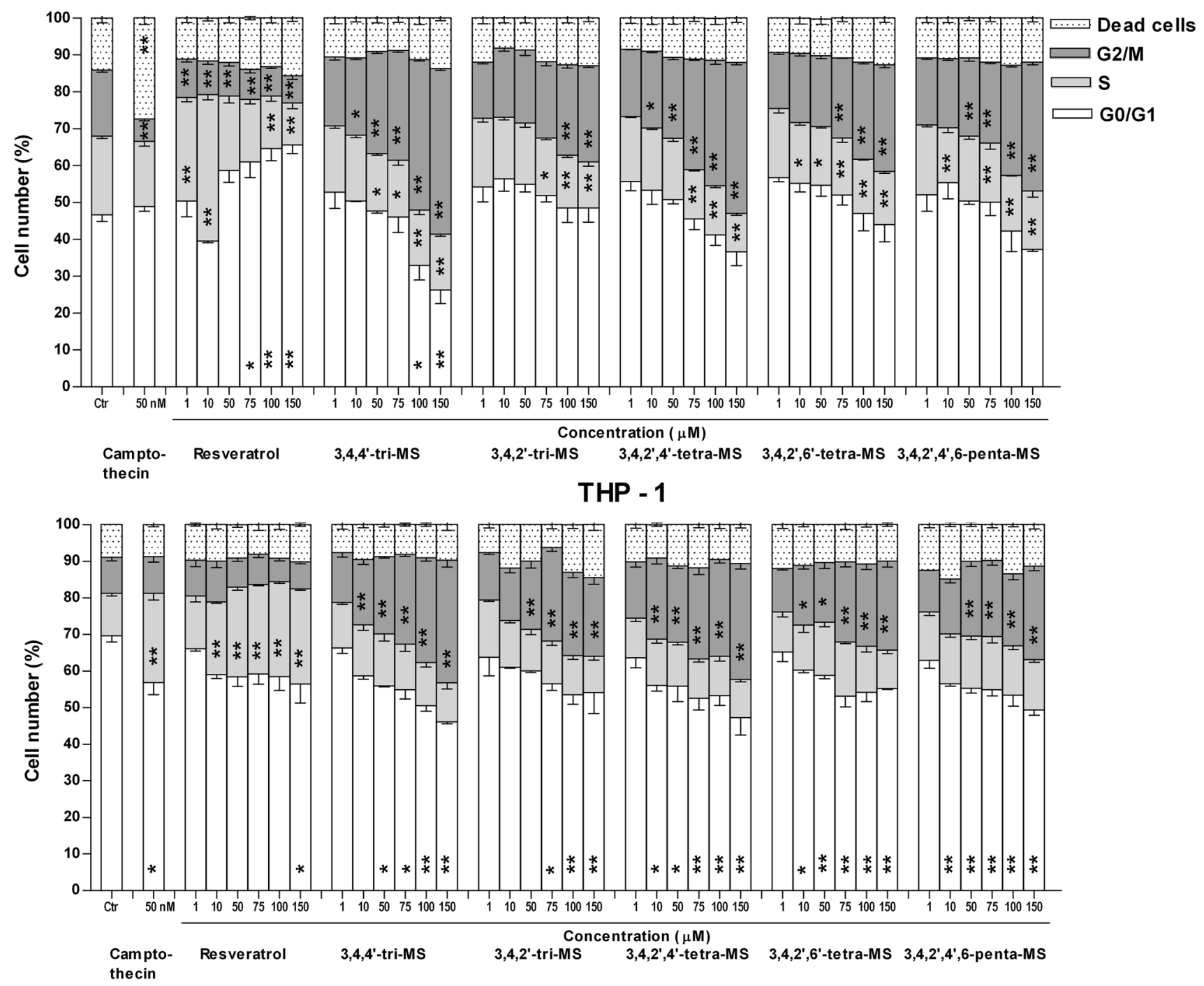

Fig. 2 Cell cycle distribution in human myeloid leukemia cells after $24 \mathrm{~h}$ of incubation with resveratrol and methoxy stilbenes followed by propidium iodide labeling and flow cytometry analysis. Camptothecin at the final concentration of $50 \mathrm{nM}$ was used as a positive control. Results of three independent experiments are presented as mean \pm SEM. $* p<0.05$, $* * p<0.01$ compared to untreated control using ANOVA followed by Dunnett's test 


\section{The effect of RSV and methoxy stilbenes on the induction of apoptosis}

Figure 3 shows the effect of RSV and its methoxy derivatives on the induction of apoptosis as assessed by Annexin V/PI staining. Treatment with all stilbenes induced apoptosis in both cell lines, particularly at their late stage.

The apoptotic rate was higher in THP-1 cells, and $3,4,4^{\prime}$-tri-MS was the most efficient inducer of this process.
The same compound also seemed to be the most efficient apoptosis inducer in HL-60 cells, but only slightly exceeded RSV and 3,4,2',4'-tetra-MS.

\section{The effect of RSV and methoxy stilbenes on the p53, $\mathrm{Bax}$, and Bcl-xI protein levels}

To understand the mechanism of stilbene-induced apoptosis, the levels of the proapoptotic protein Bax and the
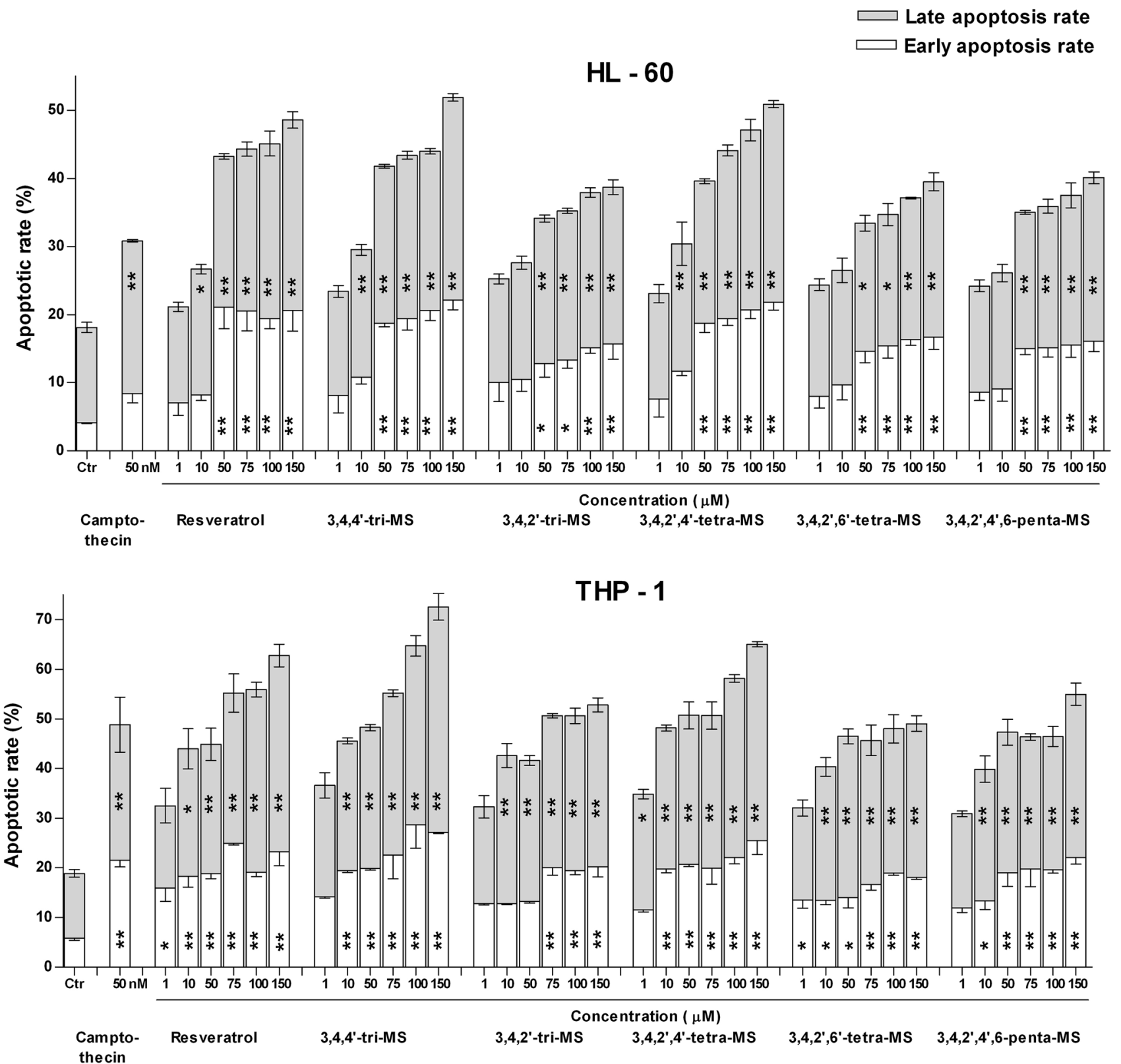

Fig. 3 Phosphatidylserine externalization measured by Annexin $\mathrm{V}$ and PI double staining in human myeloid leukemia cells after $24 \mathrm{~h}$ of incubation with resveratrol and methoxy stilbenes. Camptothecin at the final concentration of $50 \mathrm{nM}$ was used as a positive control. Results of three independent experiments are presented as mean \pm SEM. ${ }^{*} p<0.05, * * p<0.01$ compared to untreated control using ANOVA followed by Dunnett's test 
antiapoptotic protein $\mathrm{Bcl}-\mathrm{xl}$ along with $\mathrm{p} 53$ were evaluated. The results are shown in Figs. 4, 5, 6.

The $\mathrm{p} 53$ protein level was increased in both cell lines after treatment with 3,4,4'-tri-MS and 3,4,2',4'-tetra-MS at the concentration of $150 \mu \mathrm{M}$. At lower concentrations (50 and $100 \mu \mathrm{M}$ ), an increased p53 protein level was found in only HL-60 cells. The treatment with these derivatives increased the ratio of proapoptotic Bax to antiapoptotic Bcl-xl.

\section{Discussion}

The present study evaluated the cytotoxic effect of five methoxy analogs of RSV differing in the number and position of substituted hydroxyl groups on human promyelocytic cells HL-60 and human monocytic leukemia cells THP-1. Significant differences were found in the susceptibility of these cell lines to all stilbenes, including RSV. THP- 1 cells were more resistant to cytotoxic activity of these compounds than HL-60 cells. The cytotoxicity of RSV and its possible mechanism has been the subject of several studies, together with the cells used in our current investigation. Interestingly, an early study by Ferry-Dumazet et al. [2] showed an opposite effect of RSV on these cell lines. THP-1 cells showed higher sensitivity to RSV than HL-60 cells. The reasons for this discrepancy might be the longer time of exposure (72 h) and the different cytotoxicity assay applied in the above study. In contrast to the MTT assay used in our study, trypan blue exclusion test measures dead cells, while the MTT assay measures viable and proliferating cells. On the other hand, comparable value of $\mathrm{IC}_{50}$ value for RSV in HL-60 cells was found by Li et al. [17].

Among the methoxy stilbenes, 3,4,4'-tri-MS showed the highest cytotoxicity, followed by $3,4,2^{\prime}, 4^{\prime}$-tetra-MS with the lowest $\mathrm{IC}_{50}$ values in both cell lines. In our previous study, naturally occurring tri-MS substituted in the positions 3,5,4' was also more cytotoxic (by $40-50 \%$ ) than RSV and pterostilbene (3,5-dimethoxy-4-hydroxystilbene) in C6 rat glioma cells, but in much less extent in human T98G glioma cells [13].

Our recent study (unpublished data) showed that among the RSV analogs evaluated, 3,4,2',4'-tetra-MS showed the highest cytotoxicity, while $3,4,2^{\prime}, 6^{\prime}$-tetra-MS showed the lowest toxicity in $\mathrm{T} 98 \mathrm{G}$ glioma cells.

These observations suggest that not only the number but also the positions of methoxy groups in stilbene rings influence cytotoxicity. Moreover, similar to that of RSV, the cytotoxicity of methoxy stilbenes is clearly cell-specific. In this regard, Takashina et al. [18] demonstrated that RSV is more cytotoxic and can induce apoptotic cell death in human

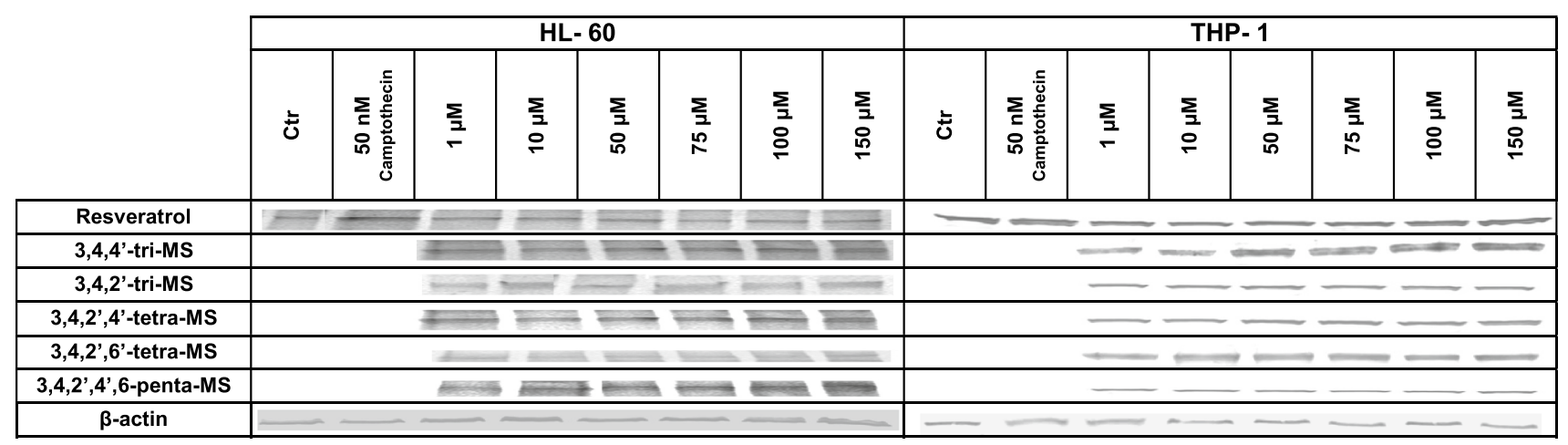

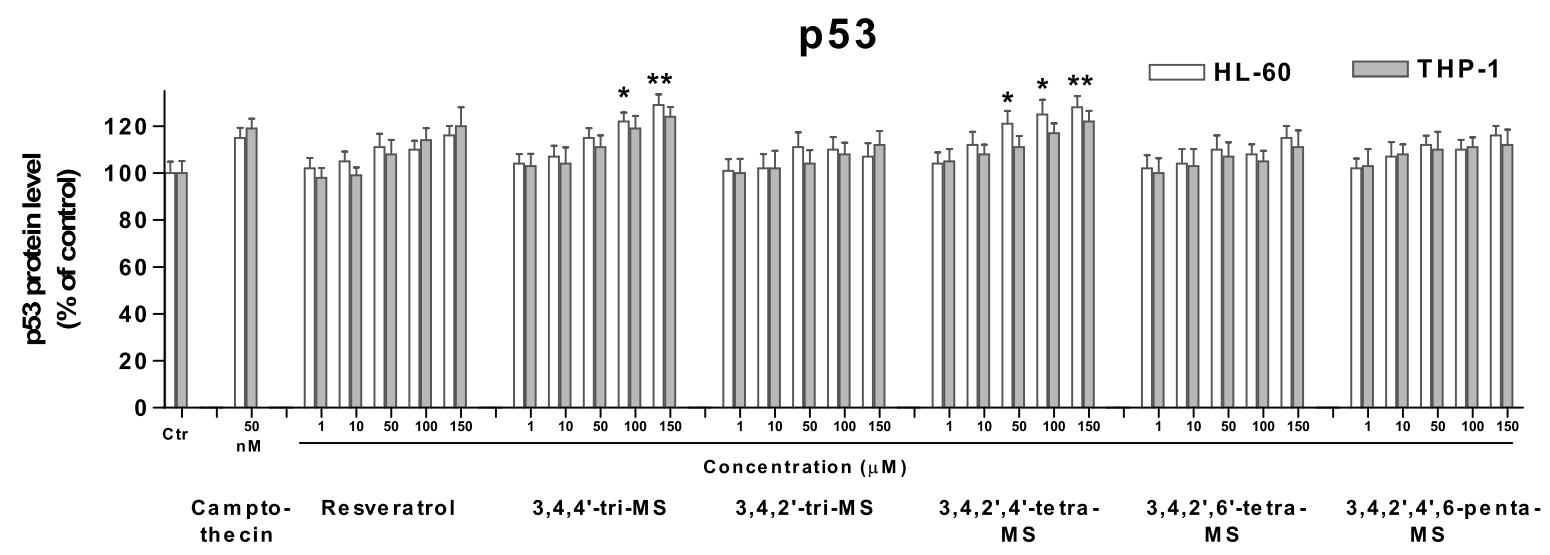

Fig. 4 The p53 protein level in HL-60 and THP-1 cells treated with resveratrol and methoxy stilbenes, as determined by Western blot analysis. Results of three independent experiments are presented as mean \pm SEM. $* p<0.05$ compared to untreated control 


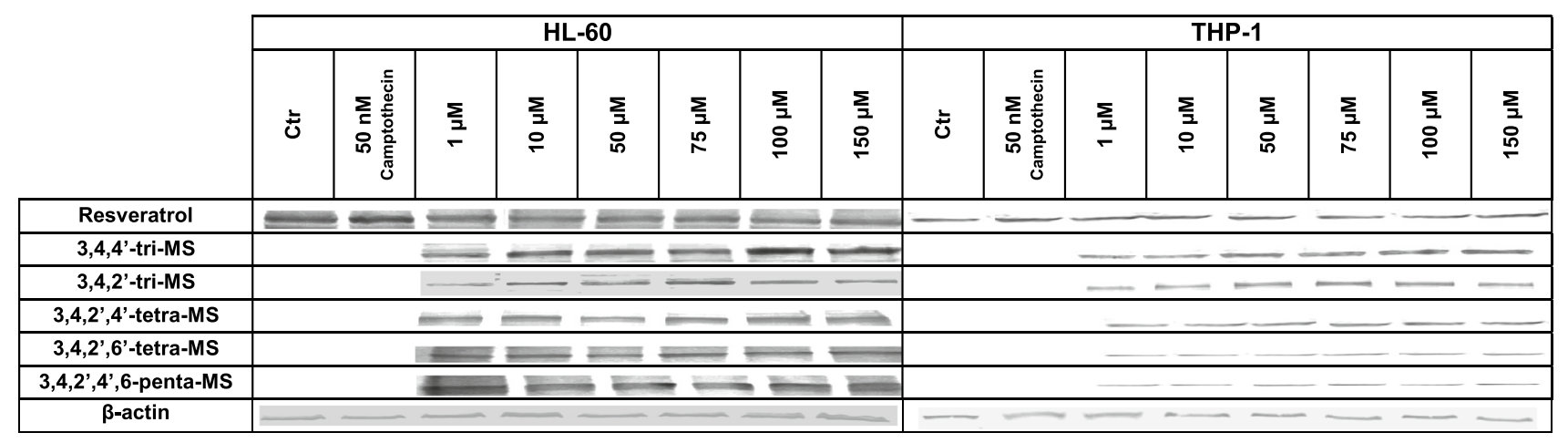

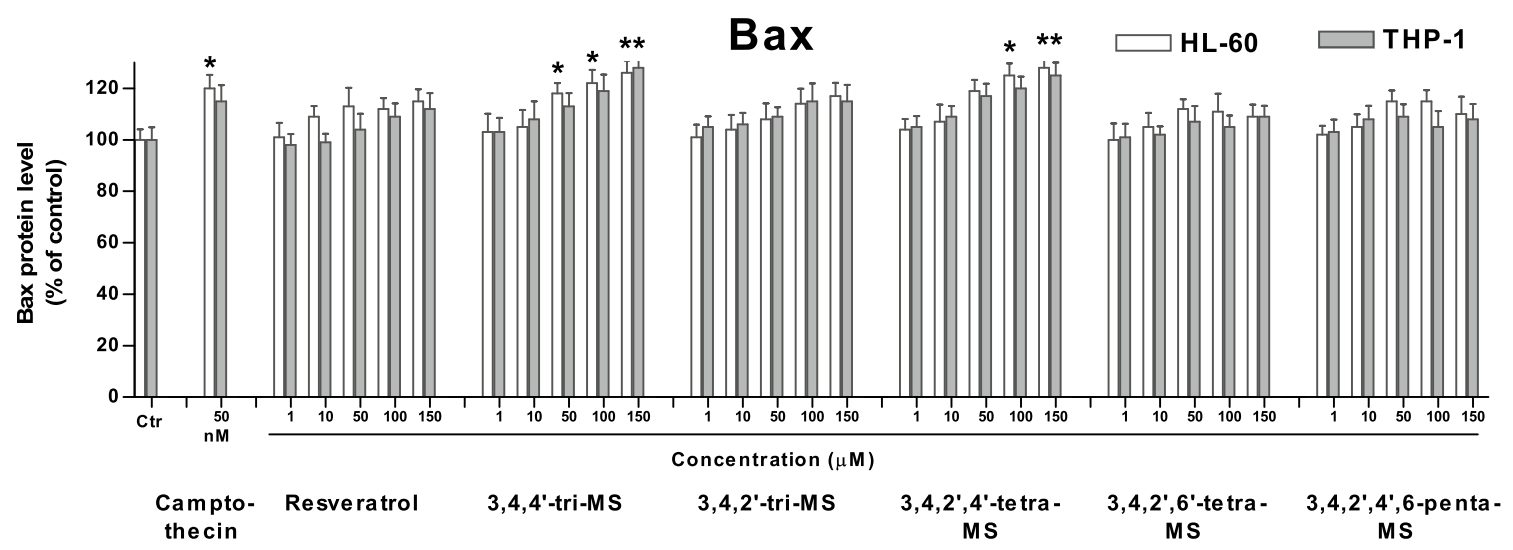

Fig. 5 The Bax protein level in HL-60 and THP-1 cells treated with resveratrol and methoxy stilbenes, as determined by Western blot analysis. Results of three independent experiments are presented as mean \pm SEM. $* p<0.05$ compared to untreated control

leukemic cells to a greater extent than in human solid tumor cells. Here, we found differences between leukemia cells of different origin in the susceptibility to the tested stilbenes.

Similar differences were observed in the effect of the tested stilbenes on cell cycle distribution. Moreover, camptothecin, which was used as a positive control, also differently affected cell cycle distribution in these two leukemic cell lines. This topoisomerase I inhibitor is known to arrest cell cycle in the S phase [19]. This effect was observed in THP-1 cells, but in HL-60 cells, a significant increase in the number of dead cells was observed after camptothecin treatment. This finding suggests that the latter cells are also more sensitive to camptothecin. As previously reported by us and other authors, RSV increased the percentage of cells in the $S$ phase [13, 20-23]. Interestingly, in HL-60 cells, this effect was mainly seen after treatment with the lowest concentrations of RSV. This effect may be related to hormesis shown by RSV in some systems [24].

Methoxy stilbenes tended to enhance the percentage of cells in the G2/M phase. In both cell lines, a clear concentration-dependent relationship was observed, with the most significant increase after treatment with 3,4,4'-tri-MS and $3,4,2^{\prime}, 4^{\prime}$-tetra-MS, thus in agreement with their highest cytotoxicity. Consequently, the increased rate of apoptosis, particularly a higher percentage of late apoptotic cells, was observed in THP-1 cells after treatment with all stilbenes, but the highest effect was observed after treatment with 3,4,4'-tri-MS.

An earlier study by Traversi et al. [25] showed that the most extensively studied 3,5,4'-tri-MS, in contrast to RSV that delays proliferation of cancer cells during the $\mathrm{S}$ phase, causes cell cycle arrest at the G2/M phase, thus showing a different way of delaying cell cycle progression. Therefore, the results of the present study confirm a similar effect for 3,4,4'-tri-MS. Moreover, this group provided evidence that the substitution of hydroxyl groups with methoxy ones renders the interaction between the RSV derivatives with DNA and topoisomerase II much weaker due to the reduced numbers of hydrogen bonds between the methoxy derivatives, topoisomerase II, and DNA. It is possible that the most active methoxy stilbenes evaluated in our study act in a similar way, but further studies are required to confirm this possibility.

To determine the possible mechanism of apoptosis induction, the protein levels of $\mathrm{p} 53, \mathrm{Bax}$, and Bcl-xl were assessed. The p53 pathway has been shown to mediate cellular stress responses as p53 can initiate DNA repair, cell cycle arrest, and apoptosis [26]. The latter is activated to 


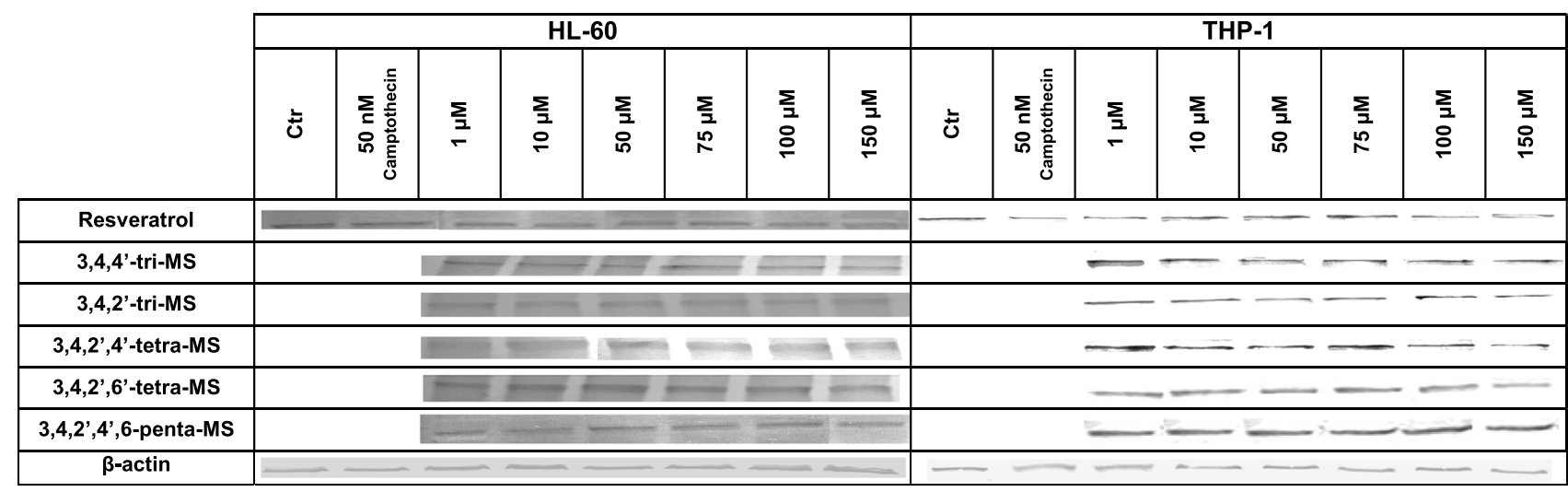

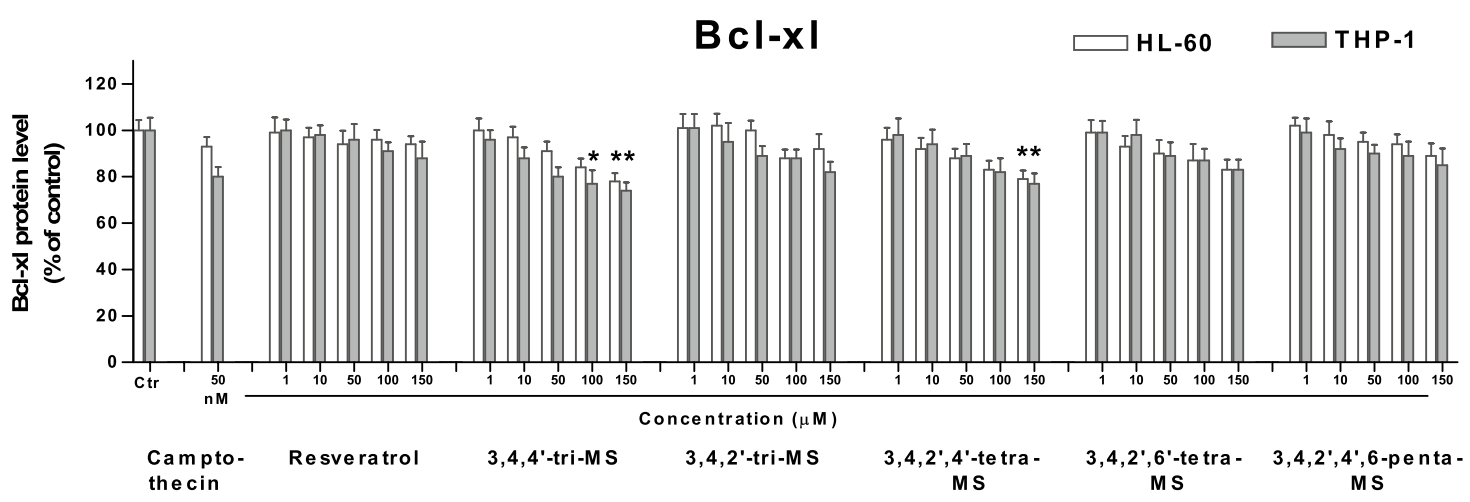

Fig. 6 The Bcl-xl protein level in HL-60 and THP-1 cells treated with resveratrol and methoxy stilbenes, as determined by Western blot analysis. Results of three independent experiments are presented as mean \pm SEM. $* p<0.05$ compared to untreated control

eliminate cells with severe DNA damage and thereby inhibit the transfer of damaged DNA to daughter cells [27]. This mechanism may be involved in the proapoptotic activity of 3,4,4'-tri-MS and 3,4,2',4'-tetra-MS, which at highest concentrations (100 and $150 \mu \mathrm{M}$ for tri-MS and $50-150 \mu \mathrm{M}$ for tetra-MS) increased the p53 protein level, particularly in HL-60 cells.

Moreover, treatment with these derivatives increased the ratio of the proapoptotic protein Bax to the antiapoptotic protein Bcl-xl. This effect might be related to the increased level of $\mathrm{p} 53$, which controls the transcription of these proteins [28]. This finding suggests that 3,4,4'-tri-MS and $3,4,2^{\prime}, 4^{\prime}$-tetra-MS induce apoptosis through the intrinsic mitochondria pathway in both cell lines.

To summarize, our study showed that 3,4,4'-tri-MS and $3,4,2^{\prime}, 4^{\prime}$-tetra-MS exhibited higher cytotoxicity toward human promyelocytic (HL-60) and monocytic leukemia (THP-1) cells than RSV and other methoxy stilbenes. This activity might be related to cell cycle arrest at the G2/M phase and induction of apoptosis. Further studies, which will include the detailed analysis of cell cycle and apoptosis regulating proteins, are required to fully elucidate the mechanism of these activities.

Funding This funding was supported by Poznan University of Medical Sciences (2019).

\section{Compliance with ethical standards}

Conflict of interest The authors confirm that there is no conflict of interest.

Open Access This article is licensed under a Creative Commons Attribution 4.0 International License, which permits use, sharing, adaptation, distribution and reproduction in any medium or format, as long as you give appropriate credit to the original author(s) and the source, provide a link to the Creative Commons licence, and indicate if changes were made. The images or other third party material in this article are included in the article's Creative Commons licence, unless indicated otherwise in a credit line to the material. If material is not included in the article's Creative Commons licence and your intended use is not permitted by statutory regulation or exceeds the permitted use, you will need to obtain permission directly from the copyright holder. To view a copy of this licence, visit http://creativecommons.org/licenses/by/4.0/. 


\section{References}

1. Berman AY, Motechin RA, Wiesenfeld MY, Holz MK (2017) The therapeutic potential of resveratrol: a review of clinical trials. NPJ Precis Oncol 1:6-15. https://doi.org/10.1038/s41698-017-0038-6

2. Ferry-Dumazet H, Garnier O, Mamani-Matsuda M, Vercauteren J, Belloc F, Billiard C, Dupouy M, Thiolat D, Kolb JP, Marit G, Reiffers J, Mossalayi MD (2002) Resveratrol inhibits the growth and induces the apoptosis of both normal and leukemic hematopoietic cells. Carcinogenesis 23:1327-1333. https://doi. org/10.1093/carcin/23.8.1327

3. Sui T, Ma L, Bai X, Li Q, Xu X (2014) Resveratrol inhibits the phosphatidyl inositide 3-kinase/protein kinase B/mammalian target of rapamycin signaling pathway in the human chronic myeloid leukemia K562 cell line. Oncol Lett 7:2093-2098. https://doi. org/10.3892/ol.2014.2014

4. Bernhard D, Tinhofer I, Tonko M, Hubl H, Ausserlechner MJ, Greil R, Kofler R, Csordas A (2000) Resveratrol causes arrest in the S-phase prior to Fas-independent apoptosis in CEM-C7H2 acute leukemia cells. Cell Death Differ 7:834-842

5. Frazzi R, Guardi M (2017) Cellular and molecular targets of resveratrol on lymphoma and leukemia cells. Molecules 22:885-901. https://doi.org/10.3390/molecules22060885

6. Fan E, Jiang S, Zhang L, Bai Y (2008) Molecular mechanism of apoptosis induction by resveratrol, a natural cancer chemopreventive agent. Int J Vitam Nutr Res 78:3-8. https://doi. org/10.1024/0300-9831.78.1.3

7. Zhang W, Go ML (2011) Methoxylation of resveratrol: effects on induction of $\mathrm{NAD}(\mathrm{P}) \mathrm{H}$ quinone-oxidoreductase 1 (NQO1) activity and growth inhibitory properties. Bioorg Med Chem Lett 21:1032-1035. https://doi.org/10.1016/j.bmcl.2010.12.029

8. Kang SY, Lee JK, Choi O, Kim CY, Jang JH, Hwang BY, Hong YS (2014) Biosynthesis of methylated resveratrol analogs through the construction of an artificial biosynthetic pathway in E. coli. BMC Biotechnol 14:67-78. https://doi.org/10.1186/1472-6750-14-67

9. Piotrowska H, Myszkowski K, Abraszek J, Kwiatkowska-Borowczyk E, Amarowicz R, Murias M, Wierzchowski M, JodynisLiebert J (2014) DMU-212 inhibits tumor growth in xenograft model of human ovarian cancer. Biomed Pharmacother 68:397400. https://doi.org/10.1016/j.biopha.2014.02.001

10. Piotrowska-Kempisty H, Klupczyńska A, Trzybulska D, Kulcenty K, Sulej-Suchomska AM, Kucińska M, Mikstacka R, Wierzchowski M, Murias M, Baer-Dubowska W, Kokot Z, JodynisLiebert J (2017) Role of CYP1A1 in the biological activity of methylated resveratrol analogue, 3,4,5,4'-tetramethoxystilbene (DMU-212) in ovarian cancer A-2780 and non-cancerous HOSE cells. Toxicol Lett 267:59-66. https://doi.org/10.1016/j.toxle t.2016.12.018

11. Simoni D, Roberti M, Invidiata FP, Aiello E, Aiello S, Marchetti P, Baruchello R, Eleopra M, Di Cristina A, Grimaudo S, Gebbia N, Crosta L, Dieli F, Tolomeo M (2006) Stilbene-based anticancer agents: resveratrol analogues active toward HL60 leukemic cells with a non-specific phase mechanism. Bioorg Med Chem Lett 16:3245-3248. https://doi.org/10.1016/j.bmcl.2006.03.028

12. Schneider Y, Chabert P, Stutzmann J, Coelho D, Fougerousse A, Gosse F, Launay JF, Brouillard R, Raul F (2003) Resveratrol analog (Z)-3,5,4'-trimethoxystilbene is a potent anti-mitotic drug inhibiting tubulin polymerization. Int J Cancer 107:189-196. https ://doi.org/10.1002/ijc.11344

13. Zielińska-Przyjemska M, Kaczmarek M, Krajka-Kuźniak V, Łuczak M, Baer-Dubowska W (2017) The effect of resveratrol, its naturally occurring derivatives and tannic acid on the induction of cell cycle arrest and apoptosis in rat C6 and human T98G glioma cell lines. Toxicol In Vitro 43:69-75. https://doi.org/10.1016/j. tiv.2017.06.004

14. Licznerska B, Szaefer H, Wierzchowski M, Sobierajska H, Baer-Dubowska W (2017) Resveratrol and its methoxy derivatives modulate the expression of estrogen metabolism enzymes in breast epithelial cells by AhR down-regulation. Mol Cell Biochem 425:169-179. https://doi.org/10.1007/s1101 0-016-2871-2

15. Licznerska B, Szaefer H, Wierzchowski M, Mikstacka R, Papierska K, Baer-Dubowska W (2018) Evaluation of the effect of the new methoxy-stilbenes on expression of receptors and enzymes involved in estrogen synthesis in cancer breast cells. Mol Cell Biochem 444:53-62. https://doi.org/10.1007/s1101 0-017-3230-7

16. Mikstacka R, Wierzchowski M, Dutkiewicz Z, Gielara-Korzańska A, Korzański A, Teubert A, Sobiak S, Baer-Dubowska W (2014) 3,4,2'-Trimethoxy-trans-stilbene: a potent CYP1B1 inhibitor. Med Chem Comm 5:496-504. https://doi.org/10.1039/C3MD00317E

17. Li G, He S, Chang L, Lu H, Zhang H, Zhang H, Chiu J (2011) GADD $45 \alpha$ and annexin A1 are involved in the apoptosis of HL-60 induced by resveratrol. Phytomedicine 18:704-709. https://doi. org/10.1016/j.phymed.2010.11.015

18. Takashina M, Inoue S, Tomihara K, Tomita K, Hattori K, Zhao QL, Suzuki T, Noguchi M, Ohashi W, Hattori Y (2017) Different effect of resveratrol to induction of apoptosis depending on the type of human cancer cells. Int J Oncol 50:787-797. https://doi. org/10.3892/ijo.2017.3859

19. Gorczyca W, Melamed MR, Darzynkiewicz Z (1993) Apoptosis of S-phase HL-60 cells induced by DNA topoisomerases: detection of DNA strand breaks by flow cytometry using the in situ nick translation assay. Toxicol Lett 67:249-258. https://doi. org/10.1016/0378-4274(93)90060-B

20. Schneider Y, Vincent F, Duranton B, Badolo L, Gosse F, Bergmann C, Seiler N, Raul F (2000) Anti-proliferative effect of resveratrol, a natural component of grapes and wine, on human colonic cancer cells. Cancer Lett 158:85-91. https://doi. org/10.1016/S0304-3835(00)00511-5

21. Park JW, Choi YJ, Jang MA, Lee YS, Jun DY, Suh SI, Baek WK, Suh MH, Jin IN, Kwon TK (2001) Chemopreventive agent resveratrol, a natural product derived from grapes, reversibly inhibits progression through $\mathrm{S}$ and $\mathrm{G}_{2}$ phases of the cell cycle in U937 cells. Cancer Lett 163:43-49. https://doi.org/10.1016/S0304 -3835(00)00658-3

22. Joe AK, Liu H, Suzui M, Vural ME, Xiao D, Weinstein IB (2002) Resveratrol induces growth inhibition, S-phase arrest, apoptosis, and changes in biomarker expression in several human cancer cell lines. Clin Cancer Res 8:893-903

23. El-Mowafy AM, Alkhalaf M (2003) Resveratrol activates adenylyl-cyclase in human breast cancer cells: a novel, estrogen receptor-independent cytostatic mechanism. Carcinogenesis 24:869-873. https://doi.org/10.1093/carcin/bgg015

24. Calabrese EJ, Hoffmann GR, Stanek EJ, Nascarella MA (2010) Hormesis in high-throughput screening of antibacterial compounds in E. coli. Hum Exp Toxicol 29:667-677. https://doi. org/10.1177/0960327109358917

25. Traversi G, Fiore M, Leone S, Basso E, Di Muzio E, Polticelli F, Degrassi F, Cozzi R (2016) Resveratrol and its methoxy-derivatives as modulators of DNA damage induced by ionising radiation. Mutagenesis 31:433-441. https://doi.org/10.1093/mutage/gew00 2

26. Vazquez A, Bond EE, Levine AJ, Bond GL (2008) The genetics of the p53 pathway, apoptosis and cancer therapy. Nat Rev Drug Discov 7:979-987. https://doi.org/10.1038/nrd2656 
27. Ozaki T, Nakagawara A (2011) Role of p53 in cell death and human cancers. Cancers (Basel) 3:994-1013. https://doi. org/10.3390/cancers3010994

28. Kim YA, Choi BT, Lee YT, Park DI, Rhee SH, Park KY, Choi YH (2004) Resveratrol inhibits cell proliferation and induces apoptosis of human breast carcinoma MCF-7 cells. Oncol Rep 11:441-446. https://doi.org/10.3892/or.11.2.441

Publisher's Note Springer Nature remains neutral with regard to jurisdictional claims in published maps and institutional affiliations. 